\section{Nuclei Isolation from Bone Cells for Nuclear Run-on Assays}

BioTechniques 23:422-424 (September 1997)

Nuclear run-on assay is the most sensitive method to measure specific gene transcription. This assay is used to determine whether a change in the mRNA level of a specific gene results from a change in its synthesis. The nuclear run-on assay consists of four steps: $(i)$ isolation of intact nuclei, (ii) incubation of nuclei with [ $\left.{ }^{32} \mathrm{P}\right] \mathrm{UTP}$ and unlabeled ATP, CTP and GTP to label the nascent RNA, (iii) purification of the labeled RNA and (iv) detection of specific mRNA by hybridizing the labeled RNA with the corresponding genomic DNA or cDNA immobilized onto a nitrocellulose membrane.

The important step in the nuclear run-on assay is obtaining intact nuclei free of cell membrane and cytoplasmic materials, because the presence of these nonnuclear constituents results in poor incorporation of [32P]UTP into nascent RNA. Several methods are used to isolate intact nuclei, and the preferred method of isolation depends on the cell type. Most methods involve swelling the cells in a hypotonic buffer followed by detergent lysis (usually Nonidet ${ }^{\circledR} \mathrm{P}$ 40 [NP40]), Dounce homogenization or both, with or without pelletting through $2 \mathrm{M}$ sucrose by ultracentrifugation to free nuclei from cell membrane and cytoplasmic materials (3). Nuclei from fragile cell lines and primary cultures like lymphocytes and thymocytes are isolated by cell lysis in iso-osmotic solution with or without NP40, followed by ultracentrifugation through a $2 \mathrm{M}$ sucrose cushion (2-4).

In our studies of rat clonal osteoblast-like cells (ROS 17/2.8 and UMR 106-01), we found that none of the published methods produced intact nuclei from these cells. Moreover, to our knowledge no published reports exist describing nuclear run-on analysis of clonal cells derived from bone. We describe a simple procedure for isolating intact nuclei from these cells for a nuclear run-on assay. This procedure is a modification of the hypotonic/NP40 lysis procedure (3).
The following procedure is for $1 \times$ $10^{6}$ to $5 \times 10^{7}$ cells. Wash the monolayers twice with $5 \mathrm{~mL}$ of ice-cold phosphate-buffered saline, scrape and centrifuge in a $50-\mathrm{mL}$ polypropylene tube at $500 \times g$ for $5 \mathrm{~min}$ at $4^{\circ} \mathrm{C}$. Resuspend the cell pellet in $40 \mathrm{~mL}$ of ice-cold lysis buffer (10 mM Tris-HCl, pH 7.4, 3 mM $\mathrm{CaCl}_{2}$ and $3 \mathrm{mM} \mathrm{MgCl}_{2}$ ), and centrifuge at $500 \times g$ for $5 \mathrm{~min}$ at $4^{\circ} \mathrm{C}$. Resuspend the cells by vortex mixing the cell pellet gently for 5-10 s (vortex speed at 3 or 4 ) while adding $1 \mathrm{~mL}$ of lysis buffer dropwise, and leave the tube in ice for $10 \mathrm{~min}$. Transfer the cell suspension to an ice-cold Dounce homogenizer, add $1 \mathrm{~mL}$ of NP40 lysis buffer (1\% NP40 in lysis buffer), and break the cells with 20-25 strokes of a tight-fitting pestle. Overlay the homogenate on $6 \mathrm{~mL}$ of a $1 \mathrm{M}$ sucrose cushion (1 M sucrose in lysis buffer) in a 14-mL polypropylene tube $(17 \times 100$ mm, Falcon ${ }^{\circledR}$; Becton Dickinson Labware, Bedford, MA, USA), and centrifuge at $500 \times g$ for $30 \mathrm{~min}$ (either a fixed-angle rotor or swinging-bucket rotor can be used). Remove the supernatant carefully using a Pasteur pipet with suction, and suspend the pellet in $0.2 \mathrm{~mL}$ of ice-cold glycerol storage buffer (50 mM Tris-HCl, pH 8.3, 5 mM $\mathrm{MgCl}_{2}, 0.1 \mathrm{mM}$ EDTA and $40 \%$ glycerol) by pipetting up and down 6-10 times with a $1-\mathrm{mL}$ micropipet at 0.2 $\mathrm{mL}$. Cover the tube with its cap, and store at $-70^{\circ} \mathrm{C}$ or in liquid nitrogen. The nuclei appear intact when seen under a microscope, and the recovery is about $75 \%$ as determined by hemacytometer.

Figure 1A shows the result of a nuclear run-on assay using nuclei isolated from ROS 17/2.8 cells treated with transforming growth factor $\beta(1 \mathrm{ng} / \mathrm{mL})$ for $48 \mathrm{~h}$. Labeling of nascent RNA transcripts and purification of RNA were carried out as described (3) with the following modifications. Frozen nuclei $(200 \mu \mathrm{L})$ stored in a $14-\mathrm{mL}$ polypropylene tube were thawed at room temperature, $200 \mu \mathrm{L}$ of $2 \times$ reaction buffer $(10$ $\mathrm{mM}$ Tris- $\mathrm{HCl}, \mathrm{pH} 8.0,5 \mathrm{mM} \mathrm{MgCl}_{2}$, $300 \mathrm{mM} \mathrm{KCl}, 5 \mathrm{mM}$ dithiothreitol, 1 $\mathrm{mM}$ each of ATP, CTP and GTP) and $200 \mu \mathrm{Ci}$ of $[\alpha-32 \mathrm{P}] \mathrm{UTP}(800 \mathrm{Ci} / \mathrm{mmol}$, $10 \mathrm{mCi} / \mathrm{mL}$ ) were added, and the reaction mixture was incubated at room temperature for $30 \mathrm{~min}$ with occasional

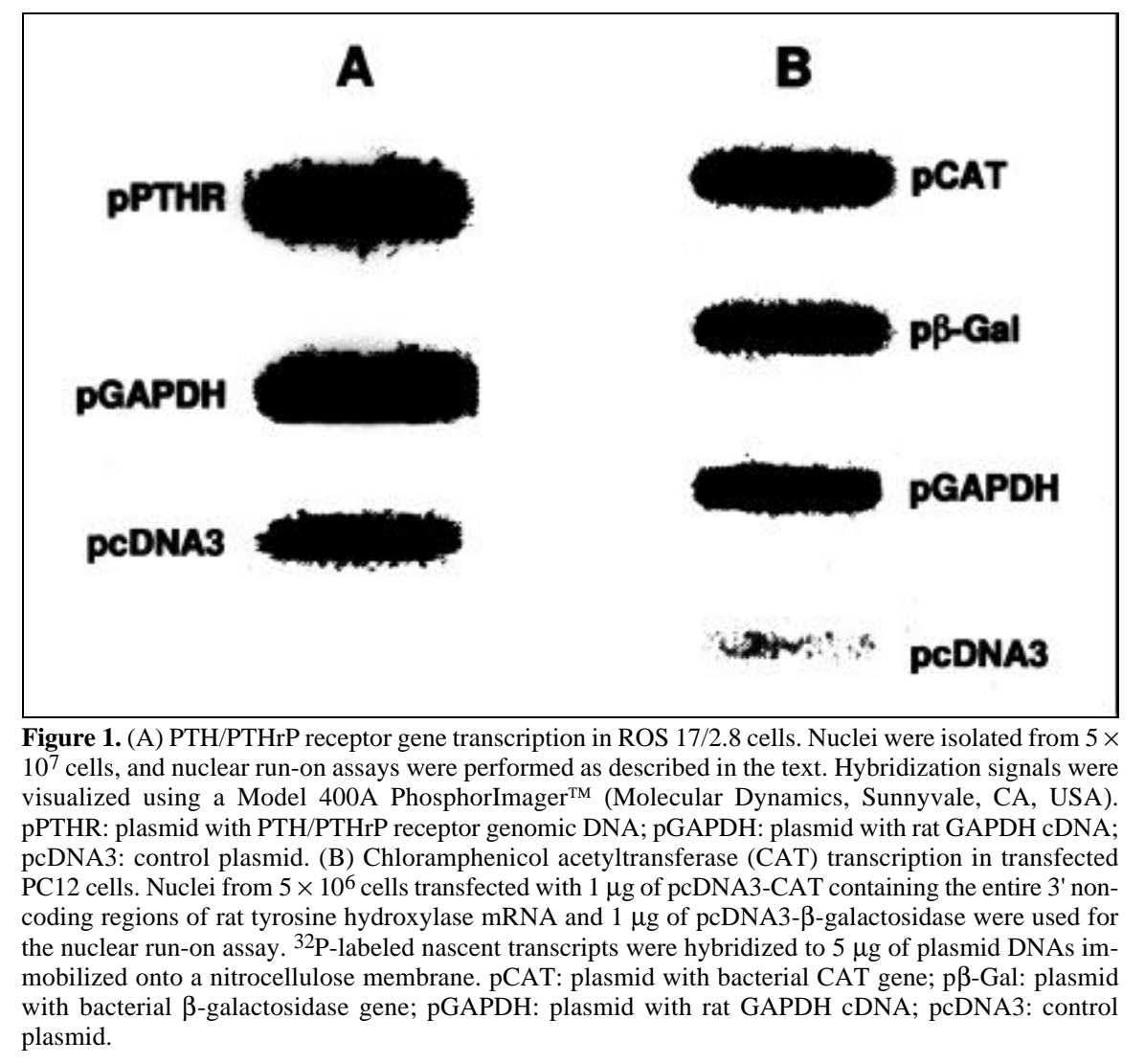


shaking. The RNA was extracted by the acid guanidinium isothiocyanate/phenol/chloroform method (1) using $2 \mathrm{~mL}$ of TRI Reagent ${ }^{\circledR}$ (Molecular Research Center, Cincinnati, OH, USA) and precipitated with ethanol in a $14-\mathrm{mL}$ Falcon polypropylene tube to avoid spilling and contamination. After precipitation at $-20^{\circ} \mathrm{C}$ for $15-30 \mathrm{~min}$, the RNA was centrifuged at $9700 \times g$ for 15 $\min$. (Note: if the centrifugation is carried out above this speed, the polypropylene tube will break.) The supernatant was removed, and the RNA pellet was dissolved in $100 \mu \mathrm{L}$ of diethyl pyrocarbonate (DEPC)-treated water. The labeled RNA was purified from unincorporated [32P]UTP using two Quick Spin ${ }^{\mathrm{TM}}$ Columns $(50 \mu \mathrm{L}$ for each column; Boehringer Mannheim, Indianapolis, IN, USA) containing Sephadex ${ }^{\circledR}$ G-50 (Pharmacia Biotech, Piscataway, NJ, USA). Detection of newly synthesized parathyroid hor- mone/parathyroid hormone-like peptide (PTH/PTHrP) receptor mRNA was carried out by hybridizing the labeled RNA to $5 \mu \mathrm{g}$ of an immobilized plasmid containing about $5000 \mathrm{bp}$ of the rat $\mathrm{PTH} / \mathrm{PTHrP}$ receptor gene (a gift from Dr. A.-B. Abou-Samra, Harvard Medical School). The assay was controlled by simultaneously measuring the newly synthesized glyceraldehyde triphosphate dehydrogenase (GAPDH) mRNA hybridizing to $5 \mu \mathrm{g}$ of a plasmid containing rat GAPDH cDNA (internal control). Similar results were obtained using nuclei isolated from UMR 106-01 cells (not shown). The method has also been used to isolate intact nuclei from PC12 cells (a cell line derived from a rat adrenal chromaffin cell tumor) for nuclear run-on assays (Figure 1B).

In summary, we describe a simple method to isolate intact nuclei from bone-derived cells and other cell types. Because the nuclei prepared by this procedure are intact and not contaminated with cell membrane and cytoplasmic organelles, the method can also be used to prepare nuclear extracts for studying the DNA-binding activity of transcription factors by electrophoretic mobility shift analysis. Additionally, in procedures where the nuclei are pelletted through a $2 \mathrm{M}$ sucrose cushion at $30000 \times g$, this ultracentrifugation step can be replaced by pelletting the nuclei through a $1 \mathrm{M}$ sucrose cushion at $500 \times g$.

\section{REFERENCES}

1.Chomczynski, P. and N. Sacchi. 1987. Single step method of RNA isolation by acid guanidinium thiocyanate-phenol-chloroform extraction. Anal. Biochem. 162:156-159.

2.Dyer, R.B. and N.K. Herzog. 1995. Isolation of intact nuclear extract preparation from a fragile B-lymphocyte cell line. BioTechniques 19:192-195.

3.Greenberg, M.E. and T.P. Bender. 1994. 


\section{Benchmarks}

Identification of newly transcribed RNA, p. 4.10.1-4.10.11. In K. Janssen (Series Ed.), Current Protocols in Molecular Biology, Vol. 1. John Wiley \& Sons, New York.

4.Olnes, M.J. and R.N. Kurl. 1994. Isolation of nuclear extracts from fragile cells: a simplified procedure applied to thymocytes. BioTechniques 17:828-829.

Address correspondence to N. Elango, GRECC (182), Audie L. Murphy Div., South Texas Veterans Health Care System, 7400 Merton Minter Blvd., San Antonio, TX 78284, USA. Internet: elangon@uthscsa. dcci.com

Received 16 October 1996; accepted 13 March 1997.

Narayanasamy Elango, Jeevalatha Vivekananda, Randy Strong and Michael S. Katz University of Texas Health Science Center at San Antonio

South Texas Veterans Health Care System San Antonio, TX, USA

\section{Ammonium Acetate Pro- tocol for the Preparation of Plasmid DNA Suitable for Mammalian Cell Transfections}

BioTechniques 23:424-427 (September 1997)

Recent progress in human genetics research has resulted in the identification of many new genes whose functions are largely unknown. To characterize these genes and their protein products, expression experiments in mammalian cells represent a logical next step. The introduction and expression of genes in mammalian cells requires successful transduction of DNA. This can be accomplished by a variety of methods, including viral infection and plasmid DNA transfection. Plasmid DNA transfection of tissue culture cells has generally used one of four techniques: (i) calcium phosphate transfection (2,9), (ii) diethyl aminoethyl (DEAE)-dextran transfection, (iii) electroporation (1,3) and (iv) liposome-mediated transfection $(4,7)$. One of the critical parameters inherent in all techniques is the availability of high-quality, pure DNA. Typically, high-quality DNA is obtained using cesium chloride/ethidium bromide ultracentrifugation or anion-exchange resins (5). Cesium chloride banding requires the use of an ultracentrifuge, is rather timeconsuming and involves expensive, toxic reagents. Anion-exchange resin chromatography, on the other hand, does not require an ultracentrifuge and can usually be accomplished in several hours. However, the resin columns are expensive and have maximal capacities, limiting the final yield of DNA. We describe a rapid, low-cost and nontoxic protocol for obtaining large quantities of plasmid DNA suitable for the transfection of mammalian cells.

The procedure used in our laboratory is a modification of the protocol reported by Lee and Rasheed (6). We adapted this protocol for large-scale DNA preparation and increased the solution 1 incubation time from 5-20 min to increase the yield of plasmid DNA. In brief, plasmid DNA is prepared from bacterial cultures grown overnight in LB broth containing $100 \mu \mathrm{g} / \mathrm{mL}$ ampicillin. Typically, bacterial cultures are allowed to achieve log growth by inoculating 2-3 $\mathrm{mL}$ of LB broth with ampicillin for $6-8 \mathrm{~h}$. This growing culture is diluted 1:100 into $250 \mathrm{~mL}$ fresh LB containing ampicillin overnight at $37^{\circ} \mathrm{C}$. Bacteria are collected by centrifugation the next morning for $5 \mathrm{~min}$ at $10000 \times g$ at $4^{\circ} \mathrm{C}$. The resulting bacterial cell pellet is resuspended in $6 \mathrm{~mL}$ of freshly made solution $1(150 \mu \mathrm{L} 1.0$ $\mathrm{M}$ Tris- $\mathrm{HCl}, \mathrm{pH} 7.6,120 \mu \mathrm{L} 0.5 \mathrm{M}$ EDTA, pH 8.0, $600 \mu \mathrm{L} 0.5 \mathrm{M}$ glucose, $12 \mathrm{mg}$ hen egg lysozyme, $5.1 \mathrm{~mL}$ of sterile, deionized water) and incubated on ice for $20 \mathrm{~min}$. Next, $12 \mathrm{~mL}$ of freshly prepared solution $2(600 \mu \mathrm{L}$ $20 \%$ sodium dodecyl sulfate [SDS], $480 \mu \mathrm{L} 5.0 \mathrm{M} \mathrm{NaOH}, 10.92 \mathrm{~mL}$ of sterile, deionized water) are added. Samples are mixed by inversion and incubated on ice for $10 \mathrm{~min}$. Finally, $9 \mathrm{~mL}$ of ice-cold 7.5 M ammonium acetate $(\mathrm{pH}$ 7.6) are added. The sample is mixed by inversion and particulate matter broken up by vigorous shaking for 5-10 s prior to another 10-min incubation on ice. Centrifugation is accomplished at $10000 \times g$ for $10 \mathrm{~min}$ at $4^{\circ} \mathrm{C}$ in a refrigerated centrifuge. After centrifugation, the supernatant is transferred to a fresh tube, and 0.6 vol of isopropanol is added. Samples are mixed by inversion and incubated for $10 \mathrm{~min}$ at room temperature prior to centrifugation at $10000 \times \mathrm{g}$ for $10 \mathrm{~min}$ at $4^{\circ} \mathrm{C}$ in a refrigerated centrifuge. After centrifugation, the pellet (containing crude plasmid DNA) is resuspended in $4 \mathrm{~mL}$ of $2.0 \mathrm{M}$ ammonium acetate $(\mathrm{pH}$ 7.4) by gentle rocking and incubated on ice for $10 \mathrm{~min}$. Centrifugation is again performed at $10000 \times g$ for $10 \mathrm{~min}$ at $4^{\circ} \mathrm{C}$ in a refrigerated centrifuge. After centrifugation, the supernatant is placed in a fresh tube, and $4 \mathrm{~mL}$ of isopropanol are added, mixed by inversion and incubated at room temperature for $10 \mathrm{~min}$. Centrifugation is performed at $10000 \times g$ for $10 \mathrm{~min}$ at $4^{\circ} \mathrm{C}$ in a refrigerated centrifuge. The final DNA pellet is resuspended in $2 \mathrm{~mL}$ of sterile, deionized water, and $10 \mu \mathrm{L}$ of 5$\mathrm{mg} / \mathrm{mL}$ RNase are added for $20 \mathrm{~min}$ at $37^{\circ} \mathrm{C}$. Following RNase treatment, 1 $\mathrm{mL}$ of ice-cold $7.5 \mathrm{M}$ ammonium acetate ( $\mathrm{pH} 7.6)$ is added and the sample 